\title{
The Role of Narratives in
}

\section{Socio-Technical Transitions}

Fukushima and the Energy Regimes

of Japan, Germany, and the United Kingdom

\section{Accepted Manuscript}

This is an Accepted Manuscript of an article published by Elsevier in Energy Research and Social Science, volume 11, 2016, pp. 237-246, available online: http://dx.doi.org/10.1016/j.erss.2015.11.001

(C) 2015. This manuscript version is made available under the CC-BY-NC-ND 4.0 license http://creativecommons.org/licenses/by-nc-nd/4.0/ 


\title{
The Role of Narratives in Socio-Technical Transitions
}

\author{
Fukushima and the Energy Regimes \\ of Japan, Germany, and the United Kingdom
}

\begin{abstract}
:
In order to reconfigure global socio-economic systems to be compatible with social imperatives and planetary boundaries, a transition towards sustainable development is necessary. The multi-level perspective (MLP) has been developed to study longterm transformative change. This paper complements the MLP by providing an ontological framework for studying and understanding the role of narratives as the vehicle of meaning and intermediation between individual and social collective in the context of ongoing transitions. Narratives are established as an analytical entity to unpack how disturbances at the level of the socio-technical landscape are translated into and contribute to the transformation of socio-technical regimes. To illustrate and test the approach, it is applied to the case of the Fukushima catastrophe: The narratives in relation to nuclear power in Japan, Germany and the United Kingdom are scrutinized and it is explored how these narratives have co-determined the policy responses and thus influenced ongoing transformation processes in the power sectors of the respective countries.
\end{abstract}

\section{Keywords:}

discourse analysis; transition research; landscape-regime interaction; narrative analysis; nuclear energy; renewable energy; socio-political environment; structuration theory; sustainability transitions;

a Wuppertal Institute for Climate, Environment and Energy, Wuppertal, Germany

* Corresponding author:

Lukas Hermwille, Wuppertal Institute, Doeppersberg 19, 42103 Wuppertal, Germany

E-mail: lukas.hermwille@wupperinst.org

Phone: +49 2022492284

Fax: +492022492250 


\section{Introduction}

Starting from the Club of Rome's "limits to growth"-report (Meadows, Meadows, Randers, \& Behrens, 1972) it has been increasingly evident that industrialised societies, their lifestyles, consumption patterns exceed what the planetary system can provide over the long run (Rockström et al., 2009). At the same time both within countries as well as in between countries great inequalities still exist. Basic human needs such as food, water, health and energy are not met for billions of people all over the world. The social foundations of our global society remain fragile (Leach, Raworth, \& Rockström, 2013). In other words, our global socioeconomic system is highly unsustainable and needs to be transformed.

More concretely, for the energy sector in order to abate dangerous climate change means that "[t]he stabilization of greenhouse gas concentrations at low levels requires a fundamental transformation of the energy supply system, including the long-term phase-out of unabated fossil fuel conversion technologies and their substitution by low-GHG alternatives". (IPCC, 2014, p. 46),

This certainly is a daunting task, but it is often less an economic or technical problem than a political one. Take climate change as an example: Technical options to mitigate climate change and limit global warming to below $2^{\circ} \mathrm{C}$ are available and the cost are considerably lower than many have expected and certainly much lower than the cost of inaction (IPCC, 2014). Still, change does not happen or at least not at the required speed. A reason is that the global economy is locked-in into unsustainable practices not only through the legacy of the infrastructures that have been built up in the past but also through political and institutional settings and processes that are resisting change (Unruh, 2000).

It is this socio-political environment to the various production and consumption regimes and in particular industrial and manufacturing regimes (Dosi, 1982; Turnheim \& Geels, 2013) that this paper is particularly interested in. The paper builds mainly on two strands of literature: 1) transition research, in particular the Multi-Level Perspective (MLP) as an heuristic for understanding sociotechnical transformations, (Geels, 2002, 2010a) and 2) Structuration Theory which heavily influenced the development of the MLP (Grin, Rotmans, \& Schot, 2010; Stones, 2005).

The MLP research framework separates three levels of transition analysis. The Regime level "is the rule-set or grammar embedded in a complex of engineering practices, production pro- 
cess technologies, product characteristics, skills and procedures, ways of handling relevant artefacts and persons, ways of-defining problems; all of them embedded in institutions and infrastructure.” (Rip \& Kemp, 1998, p. 338). Technological Niches “are spaces where networks of actors experiment with, and mutually adapt, greener organizational forms and ecofriendly technologies." (Smith, 2007, p. 427) In these Niches, outside or at the fringe of the socio-technical Regime, novelties and innovations can emerge and mature under protected conditions (Smith \& Raven, 2012). The socio-technical Landscape level "forms a broad exogenous environment that as such is beyond the direct influence of regime and niche actors" (Geels \& Schot, 2010, p. 23).

A necessary condition for a successful socio-technical transformation in a given field is the existence of both successful innovation activities in niches and external pressure on the sociotechnical regime coming from the landscape level: "There is no simple cause or driver in transitions. Instead, there is co-evolution within and between levels, i.e., processes at multiple dimensions and levels simultaneously. Transitions come about when these processes link up and reinforce each other.” (Geels \& Schot, 2010, p. 27).

However, the three levels and their respective interactions have not received equal scholarly attention in the past. There is substantial literature available on niches: What the conditions are for creating a fertile soil for innovation in niches, how interactions between the niche and regime level can play out, and even how niches can be strategically managed to nurture innovation (D. A. Loorbach, 2007; Smith, 2007; Kern \& Smith, 2008; Voß, Smith, \& Grin, 2009; D. Loorbach, 2010; Smith \& Raven, 2012; Grin et al., 2010).

Interactions between the regime level and landscape level have received much less attention, though. In line with Grin et al. this article conceptualizes the socio-technical landscape as the universe of influences exogenous to the various co-existing socio-technical regimes (Grin et al., 2010). The central questions this article addresses are the following: How is the socioeconomic landscape reflected in socio-technological regimes? And how can changes in the landscape translate into socio-technical regimes?

The article sets out to explicitly integrate narratives in the conceptual framework of transition research. It introduces narratives as a key analytical entity (section 2) and formulates a theoretical framework which helps to understand how narratives can influence and in fact codetermine everyday decision-making by regime actors (section 3); it discusses how narratives contribute to delimiting the space of what is 'politically feasible', thus contribute to the inertia of regimes with respect to socio-technical change beyond technological and political poten- 
tials (section 4). The usefulness of this conceptual approach is tested by applying it to the case of the Fukushima earthquake and the associated nuclear meltdown in the Fukushima Dai-ichi power plant (section 5). This landscape shock has had significant impact on the energy regime in Japan and energy regimes worldwide. The article illustrates how differences in discursively prominent narratives in Japan, Germany, the United Kingdom have co-determined policy responses with strong effects for the ongoing structural change of the socio-technical systems, specifically changes in the power sectors of these countries. The article concludes (section 7) by evaluating the usefulness of the approach and developing ideas of how the narrative approach could be improved and expanded in the future.

\section{Definition}

What are narratives? In this article narratives are defined in line with Roe as simple stories that describe a problem, lay out its consequences and suggest (simple) solutions (Roe, 1994). Incumbent actors typically formulate their basic patterns of arguments about the challenges confronting their respective socio-technical regimes in the form of narratives. Talking of narratives is essentially talking about meaning encoded in language. This language does not only represent the facts and objects under consideration, but arguably this language also shapes the recipients' understanding of the same facts and objects through its ordering function (Gadinger, Jarzebski, \& Yildiz, 2014b). For this analysis, the 'objective truth' of narratives is not a relevant property, as the success and traction of a narrative is determined much more by its internal logic and rhetorical persuasiveness in the context of the concerns and believes of those who use them and their audience than on any empirical verification (Gadinger et al., 2014b, p. 70; Kahneman, 2012).

In this way, narratives characterize a system framing that becomes the action guidelines for the regime actors (Byrne, Smith, Watson, \& Ockwell, 2011, p. 9). However, there might also be narratives that are less visible. Narratives that are used by more marginal groups and that frame identical challenges in a different, sometimes even contradictory, way (Hermwille, 2014 , p. 39). What both have in common is that they are "subtle articulations of collective certainty" and thus describe collective rather than individual patterns of meaning (Gadinger et al., 2014b, p. 68, translation by the author). Again, this 'certainty' is not an objective one. It may as well assert certainty over objectively uncertain formations or impose uncertainty on objective certainties. An example for the latter may be seen in the strategies that "climate sceptics' apply. Despite strong scientific consensus that climate change is real and that its 
causes are anthropogenic, conservative think tanks such as the Heritage Foundation have been very successful in collaboration with a network of media outlets in establishing and maintaining a narrative of "the science is not settled yet and hence climate protection measures should not be taken as they unduly burden the economy" (Oreskes \& Conway, 2010).

Both narrative analysis and discourse analysis are concerned with language as a filter any representation of reality has to go through. While in common language both terms have substantial overlap and the semantic borders of both can be blurry, in the academic tradition there are clear differences between the two.

'Discourse' has been defined as "an ensemble of ideas, concepts and categories through which meaning is given to social and physical phenomena, and which is produced and reproduced through an identifiable set of practices." (Hajer \& Versteeg, 2005, p. 175) or as “a shared way of apprehending the world. Embedded in language, it enables those who subscribe to it to interpret bits of information and put them together into coherent stories or accounts. Discourse constructs meanings and relationships, helping define common sense and legitimate knowledge" (Dryzek, 2013, p. 9). Both definitions have in common that they refer to discourses as shared set of terms and concepts, instantiated in language, of a rather exclusive community. The ideological frameworks and shared world views of these communities are of ultimate interest of discourse analysts. The analysis of their language is the means to interpret these ideologies and world views.

Contrary to that, narrative analysis is interested in the more immediate effects of the use of language in political debate. "Stories commonly used in describing and analysing policy issues are a force in themselves, and must be considered explicitly in assessing policy options." (Roe, 1994, p. 2). Narrative analysts ask rather what language and speech does, than what it means or presupposes, which are characteristics of discourse analysis (Gadinger et al., 2014b, p. 80).

Narratives can be understood as the basic elements of discourse, as "phenomena embedded in discourses" (Urhammer \& Røpke, 2013, p. 64). However, not one narrative defines any given discourse and neither is a given narrative exclusively to be part of only one discourse. Any narrative can fit well into a variety of discourses, even if the interpretation of those who articulate a narrative or are confronted with it may vary.

Knowledge of discourse and discourse communities can complement narrative analysis as to provide a background against which the perception and interpretation of narratives by differ- 
ent actors can be understood. This is, however, limited to cases in which complexity and uncertainty do not obscure a political controversy to an extent that an identification of clear cut discourse communities is not possible anymore (Gadinger et al., 2014b, p. 80).

\section{Ontological Framework - the Micro-Level}

Structuration Theory provides the foundation for the reflection of the role of narratives as vehicle of meaning and intermediators between the individual and the social collective. In the following section an excurse through the conceptual thicket of Structuration Theory is provided in order to lay the ontological foundation on which the proposed understanding of narratives in the context of socio-technical regime transitions builds.

To comprehend how socio-technical regime transitions come about it is key to understand the relationships between reasoning and behaviour within a socio-technical regime. While the MLP is presented as "a global model of transitions that captures the overall process" (Geels \& Schot, 2010, p. 29), it is Giddens' Structuration Theory that, as an underlying model provides a multi-dimensional understanding of structure and agency within a socio-technical regime (Geels \& Kemp, 2011, p. 42; Geels, 2010b, 2014). It is this foundation in Structuration Theory where our understanding of narratives connects to the MLP heuristic.

With reference to Giddens, Stones argues for a duality of agency and structure, "agents and structures are not kept apart but [...] are mutually constitutive of each other" (Stones, 2005, p. 21). Individual behaviour is co-determined by the structures in which one operates. These structures are rules - the cognitive, interpretive frames and cultural norms - and resources economic resources and authoritative and allocative power (Stones, 2005). In acting, the agent reproduces these structures and thus closes the cycle of structuration. Giddens refers to resources as the structure of domination and to rules as the structures of legitimation (norms) and signification (meaning) (Giddens 1984).

It is this last structure of signification in which narratives play a central role to moderate between the individual and the social collective. Narratives are the key vehicle by which signification/meaning is transported. But the role of narratives is not restricted to this direct effect. Structures of legitimation frequently build on signification: Politicians have to provide meaningful explanations for their decisions. If not, legitimation will erode. Also, domination in the form of (political) power resources rests on successful narratives, as, at least in a democratic system, political power will hardly endure without legitimation. 
All three types of structure can entail objective and material elements as well as virtual elements. Both constrain and enable agency of the individual. In his Strong Structuration project, Stones elaborates further on the nature of structures. He proposes to differentiate external and internal structures (see Table 1) (Stones, 2005). External structures exist autonomously from the agent and can both constrain the actor or provide him or her with possibilities and capacities (Stones, 2005, p. 109). Internal structures as interpretive scheme within the agent can be both general dispositional as well as conjuncturally specific. General-dispositional internal structures include transposable skills, generalised world-views, classifications, typifications, people and networks and methods to adapt generalised knowledge (Stones, 2005, p. 88). Conjuncturally-specific internal structures refer to the agents' internal perception and conception of external structures.

\begin{tabular}{|l|l|l|}
\hline \multicolumn{1}{|c|}{ External Structures } & \multicolumn{2}{c|}{ Internal Structures } \\
\cline { 2 - 3 } & \multicolumn{1}{|c|}{ conjuncturally specific } & \multicolumn{1}{c|}{ general dispositional } \\
\hline - exist autonomously from agent & - situational knowledge & - transposable 'meta'-skills \\
- involve position-practices and net- & - internal perception of external & - world-views \\
worked relations & structures & - cultural, interpretive schemes \\
- physical and/or technical configura- & - expectations about behaviour of & - classifications and typifications \\
tions & networked others & \\
\hline
\end{tabular}

Table 1: Configuration of structures according to (Stones, 2005)

In this, "the concept of conjuncturally specific internal structures often acts as a hinge between external structures, on the one hand, and general-dispositional frames and agent's practices, on the other." (Stones, 2005, p. 123).

Stones highlights the role of the conjuncturally-specific internal structures as perceived knowledge of the external structures that constrain and/or enable her ability to act (Stones, 2005). But how does an individual agent generate such knowledge? How does she develop these perceptions in constellations where she has no first-hand experiences on which she could draw? She will have to revert to collective shared knowledge which is brought to her in the form of narratives.

Moreover, there is also a relational perspective through which the role of narratives becomes apparent (Garud \& Gehman, 2012; Geels, 2010b). Agents are inevitably involved in social networks. An agent will therefore have to consider the 'ghost of networked others' (Thrift 1996 cited in Stones, 2005, p. 93) in drawing on structure when acting. It is not only her perception of the external structures that guides situated practice but also the agents knowledgea- 
bility about others' internal structures (Stones, 2005, p. 93). How does one build assumptions over other peoples' internal structures as to consider the 'ghost of networked others'? Again, through communication in terms of narratives. Narratives can thus be conceptualized as intermediators between the individuals' internal structures and the social collective.

In this, narratives provide a means to build a bridge between the micro-structure of the individual and the macro-structure of collective, social knowledge. This relationship must not be understood in a deterministic way, though. The conception provided above does leave room for individual agency. It is not assumed that the conjuncturally-specific internal structures of an individual are fully determined by the repertoire of available narratives (Lawler, 2002). Instead, the individual is still free in choosing narratives that she accepts as credible and discard others that do not conform with her general-dispositional structures. On the other hand every enactment of a narrative, recurring on it in communication with others, reinforces the role of the respective narrative within the collective repertoire and underpins its structuring effect in the next iteration of the structuration cycle.

The functional contribution of narratives in the process of structuration of a given sociotechnical regime is illustrated in figure 1 below.

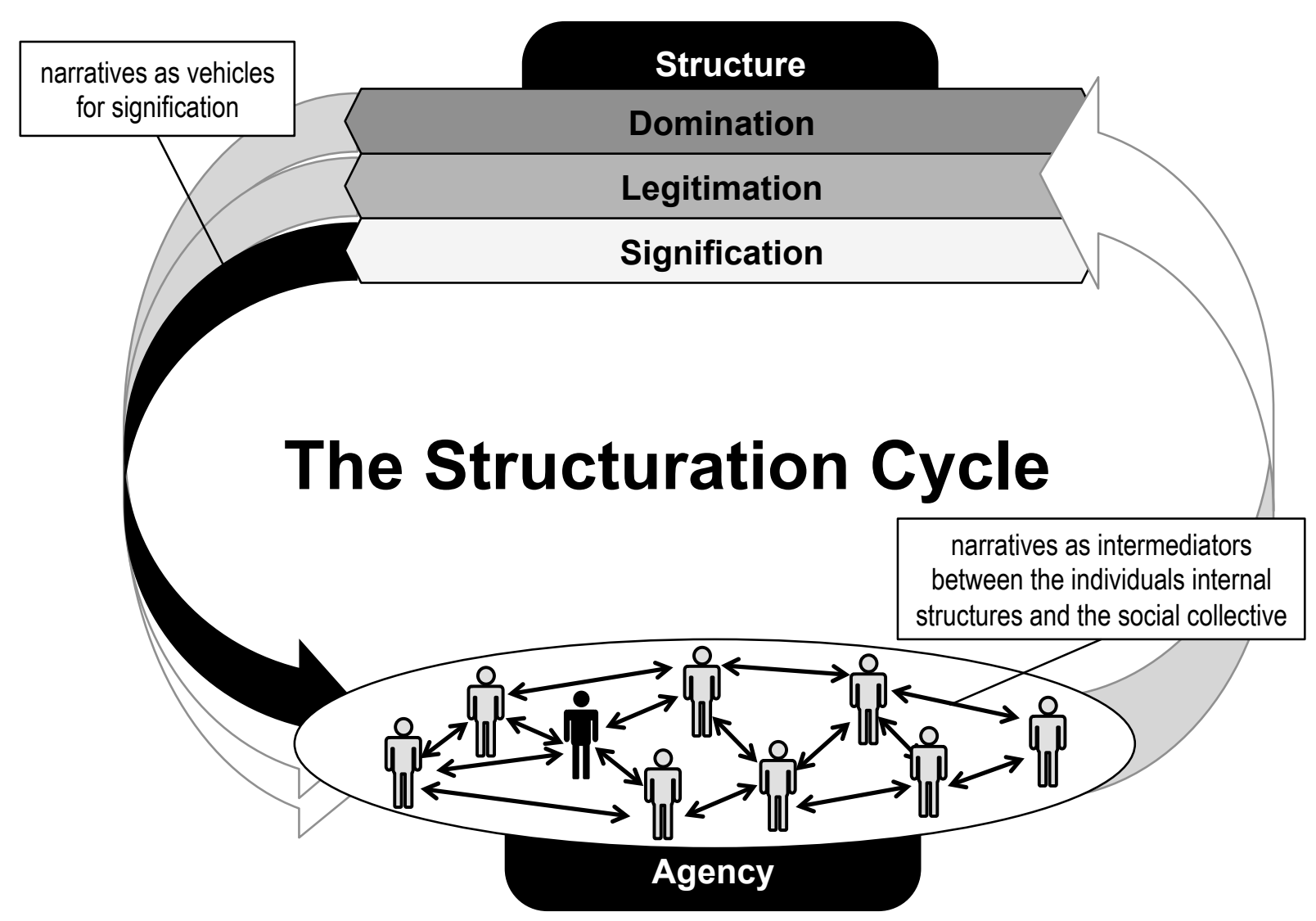

Figure 1: Illustration of the role of narratives in the structuration cycle. Author's illustration. 


\section{Narratives and Politics - the Macro Level}

Leach et al. argue that the 'system framing' that actors in political representation apply codetermines the appraisal of certain types of policies and/or technologies that often rather consolidate the status quo than bring about the kind of change that is both transformative and directed towards a sustainable system (Leach, Scoones, \& Stirling, 2010). By 'systemframing' they refer to "different ways of understanding or representing a system [...]. (T)he system boundaries, dynamics, functions and outcomes are always open to multiple, particular, contextual, positioned and subjective assumptions, methods, forms of interpretation, values and goals." (Leach et al., 2010, p. 44). Framing thus refers to a choice of perspective and assumptions and methodological approaches in line with this perspective. It is important to note, that this choice is mostly an unconscious one and often not reflected upon.

System framings can favour certain development pathways and conceal others. Narratives play a central role in this concept: they start with a particular framing of a system and its dynamics, and suggest particular ways in which these should develop or transform to bring about a particular set of outcomes. They can reveal the internal logic of the respective framing, in a certain framing only those development pathways are viable that conform with this internal logic (Leach et al., 2010).

Knowledge and understanding of the relevant narratives is central to understanding the politics of sustainability. Narratives allow investigation of the respective system framings of the actors involved in policy making. These framings co-determine the analysis and hence the basis for 'evidence-based decision making' in the policy process. As Avelino and Rotmans put it: “[B]y (...) communicating knowledge, one is exercising power, not only in terms of 'mobilising mental resources', but also in terms of influencing how other actors mobilize all the other type [sic!] of resources (human, artefactual, natural and monetary)" (Avelino \& Rotmans, 2009, p. 558).

Changes at the landscape level, external shocks or stresses influencing the socio-technical regime under consideration, have no inherent meaning. This meaning has to be constructed socially. They have to undergo a process of "'collective meaning-making' exercise that use narratives [...] to tie everyday understandings and experiences with decision-making." (Westerhoff \& Robinson, 2013, p. 205). In other words, landscape shocks and stresses have to be interpreted, cognitive relations have to be established to connect the new to the existing. This interpretation is not contingent or arbitrary. As Czarniawska put it: "[...] we are never 
the sole authors of our own narratives; in every conversation a positioning [...] takes place which is accepted, rejected or improved upon by the partners in the conversation." (Czarniawska, 2004, p. 5). "Further, narratives do not originate with the individual: rather they circulate culturally to provide a repertoire (though not an infinite one) from which people can produce their own stories" (Lawler, 2002, p. 242). Interpreting landscape change is synonymic to creating new narratives around or relating existing narratives to these shocks or stresses. Any social interpretation must be embedded in this repertoire of social collective narratives. It is this repertoire that limits the ability of political actors - policymakers, civil society and social movements - to make meaning of proposed policies and thus limits the space of the 'politically feasible'.

This change of the socio-political environment may then erode the legitimacy of incumbent industry regimes, affect financial resource flows, destabilise industrial regimes through changes in consumption patterns. If the individual effects are strong enough, this may gradually weaken the commitment of regime actors themselves (Turnheim \& Geels, 2013) and open spaces for niches to cluster with other niches and expand into more powerful nicheregimes (Avelino \& Rotmans, 2009; Haxeltine et al., 2008) or even disrupt or transform the existing regime depending on the state of the transformative process (Geels \& Schot, 2007).

The speed at which a landscape perturbation unfolds has strong implications of how it can be embedded in the repertoire of collectively shared narratives. The reason is that the development or rather the establishment of new narratives needs time. It needs time to simply spread into the relevant discourses and to unfold its structuring effect through repeated reinforcement through agency. Landscape shocks therefore must be interpreted in the context of and under the constraints that the existing repertoire of narratives imposes. Perturbations that begin with a slow onset - landscape stresses as opposed to shocks - however, may allow new narratives to develop and adjust to the changing circumstances.

\section{Methodology and Material}

In order to illustrate the functioning of narratives within socio-technical regimes, the article discusses how the devastating earthquake and tsunami in Japan and the subsequent catastrophic meltdowns at the Fukushima Dai-ichi nuclear power plant has served as a landscape shock. 
The case was chosen deliberately as it is a widely known and well-researched event for which extensive literature exists. A historian approach is applied: “...[h]istorians rarely perform formal tests of theories. Instead, they judge theories and conceptual frameworks for their usefulness in writing plausible and interesting narratives." (Turnheim \& Geels, 2013, p. 1755). Following this line of thought, the article explores the framework's usefulness in creating a plausible interpretation of the process of events of the Fukushima catastrophe and the policy responses thereafter.

The significant literature was identified in a hybrid approach. Sources from the scientific literature have been identified through a strategic snowballing approach. Recent publications on each of the three countries served as starting points from which further literature has been identified by citation snowballing (McLellan, Zhang, Utama, Farzaneh, \& Ishihara, 2013; Kingston, 2014, for Japan; Stirling, 2014c, for the United Kingdom; Mez, 2012; Schreurs, 2012, for Germany; and Skea, Lechtenböhmer, \& Asuka, 2013, for all three countries). For the case of Japan, only documents in English language have been considered.

For Germany and the United Kingdom the scientific literature was complemented with a systematic review of official government statements in the aftermath (up to 6 month) of the Fukushima accident based on the online archives of both governments (archiv.bundesregierung.de and www.gov.uk/government/announcements). In the British archive, all documents under the 'energy' category and with reference to the Fukushima event have been downloaded. Off these eight documents only six have been considered as relevant, because they were explicitly responding to the Fukushima catastrophe instead of merely referencing it (HM Government, 2011b, 2011c, 2011d, 2011e, 2011f, 2011g). From the German archive, eight official statements (parliamentary statements, press briefings) were downloaded that included the search term 'Energie' and specifically referred to energy policy and the Fukushima event (Bundesregierung der Bundesrepublik Deutschland, 2011b, 2011c, 2011d, 2011e, 2011f, 2011g, 2011h, 2011i).

Also, policy documents specifically referred to in the official statements have been added to the list of relevant literature: the UK Chief Nuclear Inspector's Report (Office for Nuclear Regulation, 2011a), the UK Committee on Climate Change's Renewable Energy Review (Committee on Climate Change, 2011), the UK National Policy Statement for Nuclear Power Generation (HM Government, 2011a), and for Germany the Report of the Ethik-Kommission (Ethik-Kommission Sichere Energieversorgung, 2011), earlier decisions on the nuclear phase- 
out (Bundesregierung der Bundesrepublik Deutschland, 2000), as well as the reversal of this phase-out in the 2010 (Deutscher Bundestag, 2010).

Given the scope of the public debate immediately after the catastrophe, it is virtually impossible to conduct a systematic review of the public response with reasonable efforts. Nevertheless the literature review was complemented with original sources such as newspaper and blog articles that provide anecdotal evidence of the public perception of official narratives.

All in all, the research approach chosen did not follow a formal protocol-driven search strategy, but included informal approaches and snowballing techniques that have been shown to be effective for cases of heterogeneous and complex policymaking questions (Greenhalgh \& Peacock, 2005, p. 1065).

\section{Case Study - Fukushima, Nuclear Power and the Re- newable Energy Transition}

The nuclear meltdown in Fukushima was the result of combination of the total station blackout, resulting from the earthquakes impact on the transmission lines and the automatic security shut-down of the nuclear plants, and the inundation of the emergency equipment as a result of the enormous tsunami that hit Fukushima after the earthquake. This combination led to a loss of cooling which, in turn, initiated cascading accidents and ultimately nuclear meltdowns in several reactors (Epstein, 2011).

Some have argued, that the combination of natural disasters in the form was 'unforeseeable' (Epstein, 2011, p. 4), but they were certainly unforeseen and left the world in a shock (IAEA, 2015). In this sense the Fukushima events can be considered a landscape shock: they were unforeseen by the actors of the socio-technical regime and exogenous to their control. The shock resonated in the socio-technical regimes of the energy sector in Japan, Germany and the United Kingdom, but differently, because the public debate around nuclear power was framed around very different narratives in the three countries.

In Japan, the dominant narrative before the nuclear disaster was: "Japan is a densely populated, relatively isolated island group and has no appreciable fossil resources of its own. Nuclear power is the only mean to secure energy supply." Calder referred to this narrative as "Japan's Energy Angst" (Calder, 2008, p. 23). Despite the traumatic experiences in the end of World War II (Hiroshima and Nagasaki), the Japanese population has borne the civilian use of nuclear power for decades, and Japan has even become a leading provider of technology for 
nuclear power plants (Calder, 2013). "Nuclear power not only promised to lower power costs for industry but also responded to both Japan's energy security and its technological ambitions.” (Samuels, 2013, p. 213).

In the United Kingdom the public debate surrounding nuclear power centred around the following narrative: "Nuclear should play a key role in taking Britain towards a clean prosperous future as it is a safe power and the lowest cost, large scale, low-carbon electricity source." (HM Government, 2011c). While in 2003, nuclear power had been dismissed in an official white paper as "unattractive" (UK Department of Trade and Industry, 2003, pp. 12, 44, 61), highly placed political figures including the Prime Minister and UK Government Chief Scientist Sir David King repeatedly presented nuclear power as being without any alternative (Stirling, 2014c). In 2008 the UK government announced the assigning of a central role to nuclear power in transforming the power sector. The UK media actively contributed to reframing nuclear power as a climate friendly technology (Doyle, 2011).

In contrast to both other countries, in Germany the debate around nuclear was not dominated by one single narrative. Instead, two strong narratives competed for dominance in the German public debate. The first of these two was the narrative of "nuclear power is a potentially catastrophic threat that we cannot control. Therefore we need a nuclear phase out as fast as technically possible." This narrative was promoted by a powerful anti-nuclear movement that established itself in Germany in the 1970s and 80s and played a key role in founding the German Green Party which was first elected into the federal parliament in 1983 (Schreurs, 2012).

However, this narrative was far from uncontested. Just five months prior to the Fukushima disaster, the German government had cancelled the first nuclear phase-out that had been agreed in 2000 (Bundesregierung der Bundesrepublik Deutschland, 2000; Deutscher Bundestag, 2010) extending the designated plant lifetimes of German nuclear power plants. The main narrative that underpinned this highly controversial decision was, that "Renewables cannot yet technically and economically cover the country's power needs. Nuclear power will act as a necessary bridging technology until it is certain that renewable sources of energy can fulfil this need.“ (Bundesregierung der Bundesrepublik Deutschland, 2000; Schreurs, 2012).

The Fukushima disaster left the world in shock and led to a re-evaluation of nuclear power worldwide. The remainder of this section discusses how this landscape shock resonated in the public debate of the three countries. 


\subsection{Japan}

The shock of the nuclear meltdown in Fukushima had an immediate effect on Japans power sector. In addition to the breakdown of the Fukushima reactors, all other nuclear power plants in Japan where shut down immediately. While the risks of nuclear power were only intermittently an issue of broad public concern in Japan at the national political level this changed dramatically after the Fukushima disaster. In 2012 Japan saw major anti-nuclear protests; public opinion had changed, turning against nuclear power (Kingston, 2013). Against this backdrop, the Japanese government massively reversed its energy policy: It proposed a strategy, according to which the country will have to survive in the medium to long term completely without nuclear power (McLellan et al., 2013). The lost nuclear share of energy production is to be compensated by the use of coal and natural gas - which reaches Japan via liquefied natural gas (LNG) freighters - as well as by renewable energy. For the first time, the development of renewable energy received attention at the highest political level. In 2010, the share of renewable energies in electricity production stood at about 5 per cent, 3.5 per cent of that from hydropower. Since then, however, a massive boom in renewable energy has begun. The feed-in tariff introduced in mid-2012 developed into a success story, especially for photovoltaics. In 2012, Japan was already in fourth place of the countries with the highest investment in renewable energy (REN21, 2013, p. 17).

However, after the re-election of Shinzō Abe as Prime Minister in December 2012, nuclear power is seeing a renaissance in Japan. Despite widespread public opposition, recent plans suggest that a reinstatement is likely of nuclear power in Japan. This development can only be explained by the strong links within the "nuclear village" (Samuels, 2013, p. 118) comprising of government, business and political institutions in which the narrative of nuclear power as a means to secure energy supply is deeply institutionalised and embedded in the socioeconomic system (Hajer, 2006),(Kingston, 2013, 2014).

\subsection{United Kingdom}

In the United Kingdom, the response on the Fukushima disaster was much less dramatic. Secretary of State for Energy and Climate Change Chris Huhne formally asked the Office of Nuclear Regulation to provide a report on the implications and lessons learnt for the UK nuclear industry (Office for Nuclear Regulation, 2011a). The report concluded that "an analysis of the Fukushima Dai-ichi accident reveals no fundamental safety weaknesses in the UKs nuclear industry but concludes that by learning lessons it can be made even safer." (Office for 
Nuclear Regulation, 2011b). Ultimately, the British Government did not alter its plans to increase the use of nuclear power in the near future.

In the United Kingdom, nuclear power was only briefly debated in terms of a potentially catastrophic threat. Immediately after the accident officials were keen to stress that British reactors are safe and did so in a very mechanic technocratic manner (HM Government, 2011b, 2011d). Unlike in Germany, an emotionally loaded narrative never entered the mainstream public debate.

Instead, the focus largely remained on the cost of energy provision (Committee on Climate Change, 2011; HM Government, 2011c, 2011d) and the fact that nuclear power can reduce dependence on energy imports. There was simply not a major discourse available in which the landscape shock could have resonated. To the contrary, some environmental commentators framed the Fukushima catastrophe even as a proof for the security of nuclear power production (Goodall \& Lynas, 2011). Nuclear power firmly remains framed as a cost-effective lowcarbon technology in the UK (Monbiot \& Chris Goodall, 2011). Revealing is also that the British Committee on Climate Change that had been established under the 2008 Climate Change Act concluded its report on renewable energy favours nuclear energy by stating inter alia that "Nuclear power currently appears to be the most cost-effective of the low-carbon technologies, and should form part of the [power] mix assuming safety concerns can be addressed" (Committee on Climate Change, 2011, p. 12)

Apparently, it is not relevant to the persuasiveness of this narrative, that nuclear power is neither cost-effective nor low-carbon. Due to emissions that occur during the entire life cycle from construction and operation through to scrapping of the equipment and the disposal of waste - nuclear power plants have significantly higher specific greenhouse gas emissions per MWh of electricity than renewable energy (Lenzen, 2008; Sovacool, 2008).

Also, the costs of new nuclear power plants have exploded. Increasing safety requirements are one reason for this. The experience with the construction of new reactors, such as in Finland and France, has shown that the construction work is often delayed for years (Thurner, Mittermeier, \& Küchenhoff, 2014; Berthélemy \& Escobar Rangel, 2015). Despite the very low global interest rates, companies have to pay extremely high risk premiums for the construction of nuclear power plants, which lead to very high capital costs. In February 2013, the news service Bloomberg reported that the French electricity company EDF would bow out as the last bidder in the race for a new nuclear power plant in the UK if the British government would not ensure the profitability of the project (Patel, 2013). Thus set under pressure, in October 2013 the British government agreed upon a minimum price with EDF of about 90 
pounds per MWh of electricity, including compensation for inflation and guaranteed for 35 years (HM Government, 2013). This price is significantly higher than the costs that are paid for most renewable energy sources, and about twice the current market price.

Recent research suggests that the British Government's strong support for nuclear energy may also be based by military-related nuclear interests, in particular maintaining infrastructure to support the fleet of nuclear propelled submarines (Johnstone \& Stirling, 2015)

\subsection{Germany}

Nowhere was the change of energy policy more rapid and radical than in Germany (Wittneben, 2012). Only four days after the earthquake and tsunami and while the nuclear catastrophe was still ongoing, the German Chancellor Angela Merkel announced a temporary shutdown of the seven oldest German nuclear plants and a safety check of all remaining plants (Bundesregierung der Bundesrepublik Deutschland, 2011b, 2011c; Schreurs, 2012). An ethics commission was established to review the ethical dimensions of energy use and to advice the German Government on the issue of nuclear power (Bundesregierung der Bundesrepublik Deutschland, 2011e). The final report of the commission explicitly referred to the narrative of nuclear power as an uncontrollable threat and recommended to phase-out nuclear power within the next decade "[...] to eliminate the risks emanating from nuclear power in Germany in the future" (Ethik-Kommission Sichere Energieversorgung, 2011, p. 4, translation by the author). In July, just four month after the Fukushima disaster and less than one year after the German Government had extended the designated plant lifetime, the German Parliament passed a new law that made the shutdown of the oldest power plants permanent and scheduling the shutdown of the remaining plants by 2022 (Bundesregierung der Bundesrepublik Deutschland, 2011h, 2011i; Schreurs, 2012).

In contrast to the British experience, the landscape shock did have a significant effect on the ongoing transformation of the energy sector in Germany. The disaster exemplified the risks that form the core of "nuclear is an uncontrollable threat"-narrative and boosted its prominence against its competing narratives. The alternative narrative of nuclear power as a bridging technology virtually vanished from official statements.

One reason, why the threat narrative became so dominant in Germany may be the lack of a credible counter-narrative. Proponents of nuclear in Germany and neighbouring countries have criticised the German policy shift as being based on an "irrational fear" (Bentzien, 2014; Döring \& Feger, 2011; Güntner, 2011; Kerngedanken.de, 2012). However, Roe argues that a 
mere critique can never develop the same persuasiveness as an original narrative. "A critique [...] never tells its own story-its point-by-point rebuttal does not have its own argument [...] and serves only to raise doubts that the critique itself cannot answer." (Roe, 1994, p. 40). In this particular case, again, the argument is supported that categories of true and false are irrelevant for the persuasiveness of the narrative. It appears irrelevant if there is a rational, i.e. scientifically probable basis for the emotional experience, the fear many opponents of nuclear power feel. The persuasiveness of the narrative of nuclear power as an uncontrollable threat does built on this emotion and not rational consideration. The "irrational fear"-critique is thus tautological.

A second reason for the profound shift of the political discourse is the fact that the threatnarrative synergetically coincided with a strong positive narrative: "Renewable energies and energy efficiency, through the strong German pioneering spirit and engineering ingenuity, can ensure both a nuclear phase out and ambitious climate protection at the same time." (Bundesregierung der Bundesrepublik Deutschland, 2011a).

Hence, the Fukushima disaster fundamentally changed the political economy of nuclear power in Germany. With important elections at state level scheduled only weeks after the earthquake and associated nuclear meltdown, Chancellor Merkel and her Government did not have another choice than revising the decision that had just been made month before (Wittneben, 2012). Consequently, the disaster at Fukushima in March 2011 is often considered to be the starting point for the German "Energiewende" and the subsequent final phase-out of nuclear power (e.g. Gerke, 2012). However, the expansion of renewable energy had already been promoted with the German feed-in tariff law (EEG) and its predecessors for over at least ten years (Jacobs, 2015). Even if this perspective is an incomplete reality, it is nonetheless indisputable that the nuclear phase-out is an integral part of the "Energiewende" in Germany (Mez, 2012). Only when it was clear to all stakeholders that nuclear energy would make no further significant contribution to the German power supply in the future, a broad political consensus to that effect could form - to close the resulting 'nuclear gap' initially with the help of renewable energy, and in the long term to rely entirely on renewable energy (Bundesregierung der Bundesrepublik Deutschland, 2011i). Hence, the nuclear debate has made a positive contribution to the "Energiewende" in Germany, by having raised the issue from a niche into a wider public. The narrative of nuclear power as an uncontrollable threat prepared the stage for the events as they unfolded in Germany. Even if discussions about the pace and arrangements of 
the "Energiewende" are heated, the phase-out of nuclear power remains a strong consensus in Germany.

\section{Concluding Remarks}

The application of a narrative perspective on the case of the Fukushima disaster and the consequent response in energy regimes in Germany, the United Kingdom and Japan has served to demonstrate the usefulness of the ontological framework for narratives in the context of transition theory developed in sections 3 and 4. Paying close attention to the prevalence and structure of narratives has aided developing an understanding of the structuration of the sociopolitical environment to the power sector regimes of the three countries. The differences in dominant narratives within the three countries have served to explain the respective policy responses to the disaster in Fukushima. It was also shown that the Fukushima disaster had a significant impact on the ongoing changes in the power sectors. Both in Japan and Germany, the event initiated or at least dramatically accelerated a shift towards renewable energies. In the United Kingdom this was not the case for lack of a persuasive narrative. Instead, some commentators even made rhetorical use of the disaster to underpin the narrative of nuclear power as a low-carbon technology and argue for its expansion.

Our analysis shows, that landscape shocks will only create enduring pressure on sociotechnical regimes if discursively prominent narratives become available that allow to translate the landscape shock into the socio-political environment of the respective regimes.

In Germany and to a lesser extent in Japan the landscape shock of the Fukushima disaster has translated into a lasting change of the socio-political environment (Turnheim \& Geels, 2013) of the socio-technical energy regimes of the two countries. In Germany a fundamental and most likely permanent shift of public opinion has occurred and this shift has lead to changes in the institutional landscape. The decision to phase out nuclear power and to replace it with renewable energies can be understood as entry point into a new transition phase of accelerated transformation for the German energy transition (Grin et al., 2010; Laes, Gorissen, \& Nevens, 2014).

In Japan, recent developments suggest that the immediate changes of public opinion and the reaction of the wider socio-political environment may not be permanent. However, even if some of nuclear power stations that have been closed down after the meltdowns in Fukushima may start to operate again, a full roll-back and a restoration of the status quo ante of nuclear 
power in Japan is highly unlikely. The recent surge of solar PV in Japan (REN21, 2013) will ultimately change the structure of the Japanese energy regime, even if on a different scale than in Germany.

The absence of corresponding narratives in the United Kingdom did not allow the landscape shock of Fukushima to resonate strong enough in the public discourses of the socio-political environment to the British energy sector. Hence, no lasting effects will remain.

Of course, it is difficult to generalize on just one very specific case; a case that was deliberatively chosen for its simplicity in order to illustrate the framework. The focus of this paper is clearly on ontology. However, there is a need to develop an epistemological concept as well that corresponds with the ontological framework outlined in this article and serves not only to analytically explore narratives in transitions ex-post, but also creatively design narratives in order to promote a transformation towards sustainability.

It may not always be as straight forward, as in our example above, to clearly identify and separate landscape disturbances. It may proof much more difficult to trace the translation of landscape stresses with slow onsets into narratives - think of see level rise or the prospect of increasing oil and gas prices towards peak oil for examples. For specific shocks it is relatively straight forward to distinguish the phases of "before the shock", "during the shock" and "after the shock". For landscape stresses it is much more difficult to identify exactly when a disturbance began, when it was identified as a potential cause for concern within the regime and when a reaction began. Another difference between the two is that a shock typically does not preclude to move back to the status quo ante once the perturbation has ceased. This was for example the case in the United Kingdom. In contrast to that, stresses typically imply that some form of adaptive change of the socio-technical regime under consideration will eventually be necessary; maintaining the status quo ante is not an option (Stirling, 2014b).

An issue that has not been covered here is the question of methodologies to trace narratives. While the historian approach applied to the case study was adequate to illustrate the theoretical framework, it may not be as appropriate to support research on transitions in the making. Other methodologies exist that approach narratives from different angles: A structuralist perspective highlighting generalizable structural elements, figures, and plots (e.g. Gadinger, Jarzebski, \& Yildiz, 2014a; Jones, Shanahan, \& McBeth, 2014) or post-positivist interpretive approaches (e.g. Roe, 1994; Czarniawska, 2004; Stone, 2012). However, none of these approaches has been applied explicitly in the context of sustainability transitions. 
If narrative research as a form of action research is to have an impact on governing sustainability transitions, there is a need for methodologies that are of an explorative nature and that are able to unveil contemporary narratives and trace them in the various discourses they contextualise. Q method may be a vantage for such methodology, that merits further exploration. Q method allows holistic assessment of the worldviews of individuals, consisting of a set of narratives they adhere to. In contrast to other means of discourse and narrative analysis that typically rely on historic and political theoretic discussions, Q method provides a way of exploring the discourses through an 'abductive' process based on empirical data (Watts \& Stenner, 2012, p. 149; Barry \& Proops, 1999). The use of Q method in policy analysis has been argued for (e.g. Barry \& Proops, 1999; Durning, 1999) and successfully applied in a wide range of fields (e.g. Dryzek, 1994; Swedeen, 2006; Frantzi, Carter, \& Lovett, 2009; Brannstrom, 2011; Forouzani, Karami, Zamani, \& Moghaddam, 2013; Cairns \& Stirling, 2014). However, the focus of these studies is more on discourses than on individual narratives. If narratives (or narrative fragments) are used as sorting items in a Q study it should be possible to shift the focus to individual narratives to trace them in and between the various discourses. Combining Q method with more conventional forms of discourse analysis could also help to develop the relational perspective on narratives and serve to disclose how narratives are used within the actor-networks of different discourse-coalitions (Hajer, 2006).

Furthermore, other methodologies exist that help to synthesise collective understanding which could be used to investigate narratives in the context of landscape shocks or stresses. One example that merits further investigation is the methodology of Structured Dialogic Design Processes (e.g. Laouris et al., 2009).

Another area where the approach presented above needs further elaboration is the role of power and political authority to promote certain narratives in order to attain political goals. This is of particular importance, because most approaches in the field of transition research are explicitly normative; they are conceptualized as research towards sustainability. But visions and concepts of sustainable futures are continuously shaped by and through social interaction by narratives and related to normative order. "Concepts such as sustainable development [...] are not and cannot simply be imposed in a top-down way, but are continuously contested in a struggle about their meaning, interpretation and implementation" (Hajer \& Versteeg, 2005, p. 176). It is therefore necessary to reflect on the mechanisms that coconstruct this vision, to be conscious of the role of incumbents to capture narratives and to use their power to divert transformations to better serve their interests (Stirling, 2014a). 
Possible vantage points of this task could be the concept of power as the ability to mobilise 'mental resources' (Avelino \& Rotmans, 2009), or notions of discursive power as promulgated by Lukes (Lukes, 1974). There are a number of efforts to bring notions of power (and politics) more explicitly into transition research (e.g. Shove \& Walker, 2007; Hendriks \& Grin, 2007; Avelino \& Rotmans, 2009; Meadowcroft, 2009, 2011; Geels, 2014; Hess, 2014; Kivimaa \& Kern, 2015). A more explicit focus on the role of narratives can probably support and complement these efforts. 


\section{References}

Avelino, F., \& Rotmans, J. (2009). Power in Transition: An Interdisciplinary Framework to Study Power in Relation to Structural Change. European Journal of Social Theory, 12(4), 543-569. http://doi.org/10.1177/1368431009349830

Barry, J., \& Proops, J. (1999). Seeking sustainability discourses with Q methodology. Ecological Economics, 28(3), 337-345. http://doi.org/10.1016/S0921-8009(98)00053-6

Bentzien, H. (2014). Top-Ökonom Sinn wirbt für Rückkehr zur Atomkraft. Retrieved 23 September 2015, from http://www.welt.de/wall-street-journal/article124496715/Top-Oekonom-Sinn-wirbt-fuer-Rueckkehr-zurAtomkraft.html

Berthélemy, M., \& Escobar Rangel, L. (2015). Nuclear reactors' construction costs: The role of lead-time, standardization and technological progress. Energy Policy, 82, 118-130.

http://doi.org/10.1016/j.enpol.2015.03.015

Brannstrom, C. (2011). A Q-Method Analysis of Environmental Governance Discourses in Brazil's Northeastern Soy Frontier. The Professional Geographer, 63(4), 531-549. http://doi.org/10.1080/00330124.2011.585081

Bundesregierung der Bundesrepublik Deutschland. (2000). Vereinbarung zwischen der Bundesregierung un den Energieversorgungsunternehmen. Retrieved from http://www.bmub.bund.de/fileadmin/bmuimport/files/pdfs/allgemein/application/pdf/atomkonsens.pdf

Bundesregierung der Bundesrepublik Deutschland. (2011a). 'Der Weg zur Energie der Zukunft' - Regierungserklärung von Bundeskanzlerin Dr. Angela Merkel zur Energiepolitik vor dem Deutschen Bundestag am 9. Juni 2011 in Berlin. Berlin.

Bundesregierung der Bundesrepublik Deutschland. (2011b, March 14). Pressestatements von Bundeskanzlerin Angela Merkel und Bundesaußenminister Guido Westerwelle zu den Folgen der Naturkatastrophen in Japan sowie den Auswirkungen auf die deutschen Kernkraftwerke. Retrieved 22 September 2015, from

http://archiv .bundesregierung.de/ContentArchiv/DE/Archiv17/Mitschrift/Pressekonferenzen/2011/03/201103-14-bkin-lage-japan-atomkraftwerke.html

Bundesregierung der Bundesrepublik Deutschland. (2011c, March 15). Statements nach dem Gespräch über die Nutzung der Kernenergie in Deutschland. Retrieved 22 September 2015, from http://archiv .bundesregierung.de/ContentArchiv/DE/Archiv 17/Mitschrift/Pressekonferenzen/2011/03/201103-15-statements-nutzung-kernenergie.html

Bundesregierung der Bundesrepublik Deutschland. (2011d, March 17). Regierungserklärung der Bundeskanzlerin Angela Merkel zur aktuellen Lage in Japan (Mitschrift). Retrieved 22 September 2015, from http://archiv.bundesregierung.de/ContentArchiv/DE/Archiv17/Regierungserklaerung/2011/2011-0317merkel-lage-japan.html

Bundesregierung der Bundesrepublik Deutschland. (2011e, April 4). Pressestatement von Bundeskanzlerin Angela Merkel vor dem Gespräch mit der Ethikkommission 'Sichere Energieversorgung'. Retrieved 22 September 2015, from

http://archiv .bundesregierung.de/ContentArchiv/DE/Archiv17/Mitschrift/Pressekonferenzen/2011/04/201104-04-merkel-ethikkommission.html

Bundesregierung der Bundesrepublik Deutschland. (2011f, April 15). Pressekonferenz Bundeskanzlerin Merkel und die Ministerpräsidenten der Länder zur Energiepolitik. Retrieved 22 September 2015, from http://archiv .bundesregierung.de/ContentArchiv/DE/Archiv 17/Mitschrift/Pressekonferenzen/2011/04/201104-15-ministerpraesidenten-energiekonzept

Bundesregierung der Bundesrepublik Deutschland. (2011g, May 30). Pressekonferenz zum Energiekonzept der Bundesregierung mit Bundeskanzlerin Merkel, BM Rösler, BM Röttgen und BM Ramsauer. Retrieved 22 September 2015, from http://archiv .bundesregierung.de/ContentArchiv/DE/Archiv17/Mitschrift/Pressekonferenzen/2011/05/201105-30-pk-bk-bm-energiekonzept.html 
Bundesregierung der Bundesrepublik Deutschland. (2011h, June 3). Pressekonferenz nach dem Gespräch der Bundeskanzlerin mit den Ministerpräsidenten der Länder zur beschleunigten Umsetzung des Energiekonzepts (Mitschrift). Retrieved 22 September 2015, from http://archiv .bundesregierung.de/ContentArchiv/DE/Archiv17/Mitschrift/Pressekonferenzen/2011/06/201106-03-energiewende-ministerpraesidenten.html

Bundesregierung der Bundesrepublik Deutschland. (2011i, June 9). Regierungserklärung von Bundeskanzlerin Angela Merkel zur Energiepolitik 'Der Weg zur Energie der Zukunft' (Mitschrift). Retrieved 22 September 2015 , from

http://archiv.bundesregierung.de/ContentArchiv/DE/Archiv17/Regierungserklaerung/2011/2011-06-09merkel-energie-zukunft.html

Byrne, R., Smith, A., Watson, J., \& Ockwell, D. (2011). Energy Pathways in Low-Carbon Development: From Technology Transfer to Socio-Technical Transformation. Brighton. Retrieved from http://stepscentre.org/wp-content/uploads/Energy_PathwaysWP1.pdf

Cairns, R., \& Stirling, A. C. (2014). 'Maintaining planetary systems' or 'concentrating global power?' High stakes in contending framings of climate geoengineering. Global Environmental Change, 28, 25-38. http://doi.org/10.1016/j.gloenvcha.2014.04.005

Calder, K. E. (2008). Japan's Energy Angst: Asia’s Changing Energy Prospects and the View from Tokyo. Strategic Analysis, 32(1), 123-129. http://doi.org/10.1080/09700160701559359

Calder, K. E. (2013). Beyond Fukushima: Japan's Emerging Energy and Environmental Challenges. Orbis, 57(3), 438-452. http://doi.org/10.1016/j.orbis.2013.05.003

Committee on Climate Change. (2011). The Renewable Energy Review. London: Committee on Climate Change established under the 2008 Climate Change Act. Retrieved from https://www.theccc.org.uk/publication/therenewable-energy-review/

Czarniawska, B. (2004). Narratives in Social Science. London: Sage Publications.

Deutscher Bundestag. (2010). Laufzeitverlängerung von Atomkraftwerken zugestimmt. Retrieved 13 September 2015, from http://www.bundestag.de/dokumente/textarchiv/2010/32009392_kw43_de_atompolitik/203098

Döring, S., \& Feger, F. (2011). Wider die Vernunft? Gehirn Und Geist, 05/2011, 31.

Dosi, G. (1982). Technological Paradigms and Technological Trajectories. Research Policy, 11, 147-162.

Doyle, J. (2011). Acclimatizing nuclear? Climate change, nuclear power and the reframing of risk in the UK news media. International Communication Gazette, 73(1-2), 107-125. http://doi.org/10.1177/1748048510386744

Dryzek, J. S. (1994). Australian discourses of democracy. Australian Journal of Political Science, 29(2), 221239. http://doi.org/10.1080/00323269408402291

Dryzek, J. S. (2013). The Politics of the Earth - Environmental Discourses (Third edition). Oxford: Oxford University Press.

Durning, D. (1999). The Transition from Traditional to Postpositivist Policy Analysis: A Role for QMethodology. Journal of Policy Analysis and Management, 18(3), 389-410.

Epstein, W. (2011). A Probabilistic Risk Assessment Practioner looks at the Great East Japan Earthquake and Tsunami. A Ninokata Laboratory White Paper, Tokyo Institute of Technology, Ninokata Laboratory. Retrieved from http://woody.com/wp-content/uploads/2011/06/A-PRA-Practioner-looks-at-the-Great-EastJapan-Earthquake-and-Tsunami.pdf

Ethik-Kommission Sichere Energieversorgung. (2011). Deutschlands Energiewende - Ein Gemeinschaftswerk für die Zukunft. Berlin: Bundesministerium für Bildung und Forschung (BMBF). Retrieved from http://www.bmbf.de/pubRD/2011_05_30_abschlussbericht_ethikkommission_property_publicationFile.pdf

Forouzani, M., Karami, E., Zamani, G. H., \& Moghaddam, K. R. (2013). Agricultural water poverty: Using Qmethodology to understand stakeholders' perceptions. Journal of Arid Environments, 97, 190-204. http://doi.org/10.1016/j.jaridenv.2013.07.003

Frantzi, S., Carter, N. T., \& Lovett, J. C. (2009). Exploring discourses on international environmental regime effectiveness with Q methodology: a case study of the Mediterranean Action Plan. Journal of Environmental Management, 90(1), 177-86. http://doi.org/10.1016/j.jenvman.2007.08.013 
Gadinger, F., Jarzebski, S., \& Yildiz, T. (Eds.). (2014a). Politische Narrative - Konzepte, Analysen, Forschungspraxis. Wiesbaden: Springer.

Gadinger, F., Jarzebski, S., \& Yildiz, T. (2014b). Vom Diskurs zur Erzählung. Möglichkeiten einer politikwissenschaftlichen Narrativanalyse. Politische Vierteljahresschrift, (1), 67-93.

Garud, R., \& Gehman, J. (2012). Metatheoretical perspectives on sustainability journeys: Evolutionary, relational and durational. Research Policy, 41(6), 980-995. http://doi.org/10.1016/j.respol.2011.07.009

Geels, F. W. (2002). Technological transitions as evolutionary reconfiguration processes: a multi-level perspective and a case-study. Research Policy, 31(8-9), 1257-1274. http://dx.doi.org/10.1016/S00487333(02)00062-8

Geels, F. W. (2010a). Ontologies, socio-technical transitions (to sustainability), and the multi-level perspective. Research Policy, 39(4), 495-510. http://doi.org/10.1016/j.respol.2010.01.022

Geels, F. W. (2010b). Ontologies, socio-technical transitions (to sustainability), and the multi-level perspective. Research Policy, 39(4), 495-510. http://doi.org/10.1016/j.respol.2010.01.022

Geels, F. W. (2014). Regime Resistance against Low-Carbon Transitions: Introducing Politics and Power into the Multi-Level Perspective. Theory, Culture \& Society, 31(5), 21-40. http://doi.org/10.1177/0263276414531627

Geels, F. W., \& Kemp, R. (2011). The multi-level perspective as a new perspective for studying socio-technical transitions. In F. W. Geels, R. Kemp, G. Dudley, \& G. Lyons (Eds.), Automobility in transition?: A sociotechnical analysis of sustainable transport. London: Routledge.

Geels, F. W., \& Schot, J. (2007). Typology of sociotechnical transition pathways. Research Policy, 36(3), 399417. http://doi.org/10.1016/j.respol.2007.01.003

Geels, F. W., \& Schot, J. (2010). The Dynamics of Transitions: A Socio-Technical Perspective. In J. Grin, J. Rotmans, \& J. Schot (Eds.), Transitions to Sustainable Development - New Directions in the Study of Long Term Transformative Change (pp. 11-104). New York: Routledge.

Gerke, T. (2012). The Road to 2020 (Part I) - Energiewende. Retrieved from http://cleantechnica.com/2012/04/05/energiewende-road-to-2020/

Goodall, C., \& Lynas, M. (2011). The dangers from nuclear power in light of Fukushima. Retrieved from http://www .carboncommentary.com/2011/03/29/the-dangers-from-nuclear-power-in-light-of-fukushima/

Greenhalgh, T., \& Peacock, R. (2005). Effectiveness and efficiency of search methods in systematic reviews of complex evidence: audit of primary sources. BMJ : British Medical Journal, 331(7524), 1064-1065. http://doi.org/10.1136/bmj.38636.593461.68

Grin, J., Rotmans, J., \& Schot, J. (2010). Transitions to Sustainable Development: New Directions in the Study of Long Term Transformative Change. New York, London: Taylor \& Francis.

Güntner, J. (2011). German Angst. Retrieved 23 September 2015, from http://www.nzz.ch/aktuell/feuilleton/uebersicht/german-angst-1.10064483

Hajer, M. (2006). Doing Discourse Analysis: Coalistions, Practices, Meaning. In M. van den Brink \& T. Metze (Eds.), Words matter in policy and Planning - Discourse Theory and Method in the Social Sciences (pp. 65-74). Utrecht: Netherlands Geographical Studies.

Hajer, M., \& Versteeg, W. (2005). A Decade of Discourse Analysis of Environmental Politics: Achievements, Challenges, Perspectives. Journal of Environmental Policy \& Planning, 7(3), 175-184. http://doi.org/10.1080/1523908050033964

Haxeltine, A., Whitmarsh, L., Bergman, N., Rotmans, J., Schilperoord, M., \& Köhler, J. (2008). A Conceptual Framework for Transition Modelling. International Journal of Innovation and Sustainable Development, 3 , 93-114.

Hendriks, C. M., \& Grin, J. (2007). Contextualizing Reflexive Governance: the Politics of Dutch Transitions to Sustainability. Journal of Environmental Policy \& Planning, 9(3-4), 333-350. http://doi.org/10.1080/15239080701622790

Hermwille, L. (2014). Energy Transformation between Conflicting Interests. In B. Kofler \& N. Netzer (Eds.), Towards a Global Energy Transformation. Berlin: Friedrich-Ebert Stiftung. 
Hess, D. J. (2014). Sustainability transitions: A political coalition perspective. Research Policy, 43(2), $278-283$. http://doi.org/10.1016/j.respol.2013.10.008

HM Government. (2011a). National Policy Statment for Nuclear Power Generation. London: Department of Energy and Climate Change.

HM Government. (2011b, March 17). Huhne: nuclear safety is number one priority. Retrieved 22 September 2015, from https://www.gov.uk/government/news/huhne-nuclear-safety-is-number-one-priority

HM Government. (2011c, May 18). Dr Mike Weightman's interim report, 'Japanese earthquake and tsunami: Implications for the UK nuclear industry' [Written Ministerial Statement]. Retrieved 22 September 2015, from https://www .gov.uk/government/news/dr-mike-weightmans-interim-report-japanese-earthquake-andtsunami-implications-for-the-uk-nuclear-industry-written-ministerial-statement-by-the-rt-hon-chris-huhnemp-18-may-2011

HM Government. (2011d, May 18). Huhne welcomes interim report from chief nuclear inspector. Retrieved 22 September 2015, from https://www.gov.uk/government/news/huhne-welcomes-interim-report-from-chiefnuclear-inspector

HM Government. (2011e, June 14). Charles Hendry speech to the CBI Energy Conference, 14 June 2011. Retrieved 22 September 2015, from https:/www.gov.uk/government/speeches/charles-hendry-speech-to-thecbi-energy-conference-14-june-2011

HM Government. (2011f, June 23). National Policy Statements: Written Ministerial Statement by The Rt Hon Chris Huhne MP. Retrieved 22 September 2015, from https:/www.gov.uk/government/news/nationalpolicy-statements-written-ministerial-statement-by-the-rt-hon-chris-huhne-mp

HM Government. (2011g, July 6). Charles Hendry's speech to the NIA Conference: The road to final investment decisions. Retrieved 22 September 2015, from https://www.gov.uk/government/speeches/charles-hendrysspeech-to-the-nia-conference-the-road-to-final-investment-decisions

HM Government. (2013). Initial agreement reached on new nuclear power station at Hinkley. Retrieved 25 November 2013, from https://www.gov.uk/government/news/initial-agreement-reached-on-new-nuclearpower-station-at-hinkley

IAEA. (2015). The Fukushima Daiichi Accident - Report by the Director General. Vienna: International Atomic Energy Agency. Retrieved from http://www-pub.iaea.org/MTCD/Publications/PDF/Pub1710ReportByTheDG-Web.pdf

IPCC. (2014). Technical Summary. In Climate Change 2014: Mitigation of Climate Change. Contribution of Working Group III to the Fifth Assessment Report of the Intergovernmental Panel on Climate Change. Cambridge: Cambridge University Press.

Jacobs, D. (2015). Drivers of transformative change: Empirical evidience from the German Energiewende. In K. Holm Olsen \& J. Fenhann (Eds.), Transformational Change for Low Carbon and Sustainable Development. Copenhagen: UNEP DTU Partnership.

Johnstone, P., \& Stirling, A. C. (2015). Comparing Nuclear Power Trajectories in Germany And the UK: From 'Regimes' to 'Democracies' in Sociotechnical Transitions and Discontinuities (SPRU Working Paper No. 2015-18). Brighton: SPRU-Science and Technology Policy Research, University of Sussex. Retrieved from http://www.sussex.ac.uk/spru/documents/2015-18-swps-johnston-stirling.pdf

Jones, M. D., Shanahan, E. A., \& McBeth, M. K. (Eds.). (2014). The Science of Stories: Applications of the Narrative Policy Framework in Public Policy Analysis. New York: Palgrave Macmillan.

Kahneman, D. (2012). Thinking, Fast and Slow. London: Penguin Random House.

Kern, F., \& Smith, A. (2008). Restructuring energy systems for sustainability? Energy transition policy in the Netherlands. Energy Policy, 36(11), 4093-4103. http://doi.org/10.1016/j.enpol.2008.06.018

Kerngedanken.de. (2012). Nein zur Atomangst! Retrieved from http://www.kerngedanken.de/2012/07/nein-zuratomangst/

Kingston, J. (2013). Nuclear Power Politics in Japan, 2011-2013. Asian Perspective, 37(4), 501-521. http://doi.org/10.5555/0258-9184-37.4.501

Kingston, J. (2014). Abe's Nuclear Renaissance. Critical Asian Studies, 46(3), 461-484. http://doi.org/10.1080/14672715.2014.935136 
Kivimaa, P., \& Kern, F. (2015). Creative Destruction or Mere Niche Creation? Innovation Policy Mixes for Sustainability Transitions (SPRU Working Paper No. 2015-02). Brighton: SPRU-Science and Technology Policy Research, University of Sussex.

Laes, E., Gorissen, L., \& Nevens, F. (2014). A Comparison of Energy Transition Governance in Germany, The Netherlands and the United Kingdom. Sustainability, 6(3), 1129-1152. http://doi.org/10.3390/su6031129

Laouris, Y., Michaelides, M., Damdelen, M., Laouri, R., Beyatli, D., \& Christakis, A. (2009). A systemic evaluation of the state of affairs following the negative outcome of the referendum in Cyprus using the structured dialogic design process. Systemic Practice and Action Research, 22(1), 45-75.

Lawler, S. (2002). Narrative in Social Research. In T. May (Ed.), Qualitative Research in Action (pp. 242-258). London: Sage Publications.

Leach, M., Raworth, K., \& Rockström, J. (2013). Between social and planetary boundaries: Navigating pathways in the safe and just space for humanity. In World Social Science Report 2013 (pp. 84-89). Paris: UNESCO / ISSC.

Leach, M., Scoones, I., \& Stirling, A. C. (2010). Dynamic Sustainabilities - Technology, Environment and Social Justice. Oxon, New York: Earthscan / Routledge.

Lenzen, M. (2008). Life cycle energy and greenhouse gas emissions of nuclear energy: A review. Energy Conversion and Management, 49(8), 2178-2199. http://doi.org/10.1016/j.enconman.2008.01.033

Loorbach, D. (2010). Transition Management for Sustainable Development: A Prescriptive, Complexity-Based Governance Framework. Governance, 23(1), 161-183. http://doi.org/10.1111/j.1468-0491.2009.01471.x

Loorbach, D. A. (2007). Transition Management - New mode of governance for sustainable development. Erasmus University Rotterdam.

Lukes, S. (1974). Power. A Radical View. London: MacMillan.

McLellan, B. C., Zhang, Q., Utama, N. A., Farzaneh, H., \& Ishihara, K. N. (2013). Analysis of Japan's postFukushima energy strategy. Energy Strategy Reviews, 2(2), 190-198. http://doi.org/10.1016/j.esr.2013.04.004

Meadowcroft, J. (2009). What about the politics? Sustainable development, transition management, and long term energy transitions. Policy Sciences, 42(4), 323-340. http://doi.org/10.1007/s11077-009-9097-z

Meadowcroft, J. (2011). Engaging with the politics of sustainability transitions. Environmental Innovation and Societal Transitions, 1(1), 70-75. http://doi.org/10.1016/j.eist.2011.02.003

Meadows, D. H., Meadows, D., Randers, J., \& Behrens, W. (1972). The limits to growth: a report for the Club of Rome's Project on the predicament of mankind. New York: Universe. New York: Univers.

Mez, L. (2012). Germany's merger of energy and climate change policy. Bulletin of the Atomic Scientists, 68(6), 22-29. http://doi.org/10.1177/0096340212464358

Monbiot, G., \& Chris Goodall. (2011). Greens must not prioritise renewables over climate change. Retrieved 19 October 2014, from http://www .theguardian.com/environment/georgemonbiot/2011/aug/08/greensrenewables-climate-change

Office for Nuclear Regulation. (2011a). Chief Nuclear Inspector's report on lessons from Fukushima. Retrieved 23 September 2015, from http://www.onr.org.uk/fukushima/final-report.htm

Office for Nuclear Regulation. (2011b). Japanese earthquake and tsunami: Implications for the UK nuclear industry (No. September). London. Retrieved from http://www.onr.org.uk/fukushima/final-report.pdf

Oreskes, N., \& Conway, E. M. (2010). Merchants of Doubt: How a Handful of Scientists Obscured the Truth on Issues from Tobacco Smoke to Global Warming. New York, London: Bloomsbury Press.

Patel, T. (2013). EDF May End U.K. Nuclear Plan Unless Profit Guaranteed, CEO Says. Retrieved 23 September 2015, from http://www.bloomberg.com/news/print/2013-02-05/edf-may-end-u-k-nuclear-plan-unlessprofit-guaranteed-ceo-says.html

REN21. (2013). Renewables 2013 - Global Status Report. Paris: REN21 - Renewable Energy Policy Network for the 21 st Century.

Rip, A., \& Kemp, R. (1998). Technological Change. In S. Rayner \& E. L. Malone (Eds.), Human choice and climate change: an international assessment (pp. 327-399). Columbus, OH: Batelle Press. 
Rockström, J., Steffen, W., Noone, K., Persson, Å., Chappin, S., III, Lambin, E., ... Foley, J. (2009). A safe operating space for humanity. Nature, 461(September), 472-475.

Roe, E. (1994). Narrative Policy Analysis. Durham: Duke University Press.

Samuels, R. J. (2013). 3.11: Disaster and change in Japan. Ithaca, NY: Cornell University Press.

Schreurs, M. (2012). The politics of phase-out. Bulletin of the Atomic Scientists, 68(6), 30-41. http://doi.org/10.1177/0096340212464359

Shove, E., \& Walker, G. (2007). CAUTION! Transitions ahead: politics, practice, and sustainable transition management. Environment and Planning A, 4(39), 763-770.

Skea, J., Lechtenböhmer, S., \& Asuka, J. (2013). Climate policies after Fukushima: three views. Climate Policy, 13(sup01), 36-54. http://doi.org/10.1080/14693062.2013.756670

Smith, A. (2007). Translating Sustainabilities between Green Niches and Socio-Technical Regimes. Technology Analysis \& Strategic Management, 19(4), 427-450. http://doi.org/10.1080/09537320701403334

Smith, A., \& Raven, R. (2012). What is protective space? Reconsidering niches in transitions to sustainability. Research Policy, 41(6), 1025-1036. http://doi.org/10.1016/j.respol.2011.12.012

Sovacool, B. K. (2008). Valuing the greenhouse gas emissions from nuclear power: A critical survey. Energy Policy, 36(8), 2950-2963. http://doi.org/10.1016/j.enpol.2008.04.017

Stirling, A. C. (2014a). Emancipating Transformations: From Controlling 'the transition' to culturing plural radical progress. Retrieved from http://steps-centre.org/wp-content/uploads/Transformations.pdf

Stirling, A. C. (2014b). From Sustainability to Transformation: Dynamics and diversity in reflexive governance of vulnerability (No. 2014-06). Brighton: Science and Technology Policy Research Unit.

Stirling, A. C. (2014c). Transforming power: Social science and the politics of energy choices. Energy Research \& Social Science, 1, 83-95. http://doi.org/10.1016/j.erss.2014.02.001

Stone, D. (2012). Policy Paradox: The Art of Political Decision Making (3rd edition). New York: Norton \& Company.

Stones, R. (2005). Structuration Theory (Traditions). Basingstoke: Palgrave Macmillan.

Swedeen, P. (2006). Post-normal science in practice: A Q study of the potential for sustainable forestry in Washington State, USA. Ecological Economics, 57(2), 190-208. http://doi.org/10.1016/j.ecolecon.2005.04.003

Thurner, P. W., Mittermeier, L., \& Küchenhoff, H. (2014). How long does it take to build a nuclear power plant? A non-parametric event history approach with P-splines. Energy Policy, 70, 163-171. http://doi.org/10.1016/j.enpol.2014.03.015

Turnheim, B., \& Geels, F. W. (2013). The destabilisation of existing regimes: Confronting a multi-dimensional framework with a case study of the British coal industry (1913-1967). Research Policy, 42(10), 17491767. http://doi.org/10.1016/j.respol.2013.04.009

UK Department of Trade and Industry. (2003). Energy White Paper: Our energy future-creating a low carbon economy. London.

Unruh, G. C. (2000). Understanding carbon lock-in. Energy Policy, 28(12), 817-830.

Urhammer, E., \& Røpke, I. (2013). Macroeconomic narratives in a world of crises: An analysis of stories about solving the system crisis. Ecological Economics, 96, 62-70. http://doi.org/10.1016/j.ecolecon.2013.10.002

Voß, J.-P., Smith, A., \& Grin, J. (2009). Designing long-term policy: rethinking transition management. Policy Sciences, 42(4), 275-302. http://doi.org/10.1007/s11077-009-9103-5

Watts, S., \& Stenner, P. (2012). Doing Q Methodological Research - Theory, Method and Interpretation. London: Sage Publications.

Westerhoff, L., \& Robinson, J. (2013). 'Practicing' narratives : Exploring the meaning and materiality of climate change. In Transformation in a changing climate (pp. 202-211). Oslo.

Wittneben, B. B. F. (2012). The impact of the Fukushima nuclear accident on European energy policy. Environmental Science \& Policy, 15(1), 1-3. http://doi.org/10.1016/j.envsci.2011.09.002 